\title{
Great crested newt (Triturus cristatus) populations are not one and the same: Scottish newts respond differently to Habitat Suitability Index (HSI) and abiotic factors
}

\author{
L.R. Harper ${ }^{1,2}$, J.R. Downie ${ }^{2}$ \& D.C. McNeill ${ }^{2}$ \\ 1Biology Department, School of Environmental Sciences, University of Hull, Kingston upon Hull, HU6 7RX \\ ${ }^{2}$ School of Life Sciences, College of Medical, Veterinary and Life Sciences, University of Glasgow, Glasgow G12 \\ 8QQ
}

E-mail: lynsey.harper2@gmail.com

\section{BACKGROUND}

McNeill et al. (2012) described the translocation of the great crested newt (Triturus cristatus) population at Gartcosh, North Lanarkshire, which is thought to be the largest Scottish population of this European-protected species. The translocation was phased over three years (2004-2006) from the original breeding site to a specially created nature reserve nearby, comprising four clusters of new ponds. In addition to over 1,000 adult great crested newts, the translocation involved thousands of common frogs (Rana temporaria), common toads (Bufo bufo), palmate newts (Lissotriton helveticus), and smooth newts (L. vulgaris). Harper et al. (2017) followed with annual monitoring results for the great crested newt population during the first ten years post-translocation. Using the standard torchlight survey method to generate peak adult counts, the great crested newt population appeared to have grown during the 10-year period, but some pond clusters had been more successful than others.

Despite the apparent success of the translocation on the whole, Harper et al. (2017) concluded that much needs to be learned about the overall habitat requirements of great crested newts in Scotland. For instance, since the new Gartcosh ponds were constructed according to best practice guidelines for habitat management (English Nature, 2001; Langton et al., 2001), why had some been more successful than others?

Most research on great crested newt habitat requirements has been carried out in England and in continental Europe. Scottish great crested newt populations are mostly small and scattered in the central belt, Dumfries and Galloway, the Borders, and a cluster of sites in the Inverness area (McInerny \& Minting, 2016). Use of environmental DNA (eDNA) analysis to identify new sites has had some successes, but within areas that have existing distribution records (Minting, 2018). A widely used method for assessing potential suitability of ponds for great crested newts is the Habitat Suitability
Index (HSI) devised by Oldham et al. (2000), but only one study has evaluated its usefulness in Scotland (O'Brien et al., 2017). Given the climatic differences between the Scottish, English, and continental ranges of the great crested newt, Scottish populations may exhibit local adaptations that are incompatible with conservation management and monitoring criteria derived from other areas. As an example, Paterson (2018) found that great crested newts at Gartcosh were active earlier in the year and at significantly lower temperatures than expected in England. Therefore, surveys of this Scottish population using recommended methodology (Langton et al., 2001) would have generated unreliable data.

\section{RECENT RESULTS}

Here, we provide a brief summary of HSI and abiotic data from Gartcosh. The detailed results will be published elsewhere (Harper et al., 2018). HSI scores for the Gartcosh ponds were largely consistent between 2006 and 2015, but some individual ponds had improved whereas others had deteriorated. In contrast to Oldham et al. (2000), we did not find a significant relationship between HSI scores and great crested newt peak or average adult counts. This would support abundance as a poor indicator of habitat quality (Unglaub et al., 2015) and the use of an adapted HSI for Scottish great crested newts (O'Brien et al., 2017). Consistent with studies on English or European great crested newt populations, we identified a positive correlation between $\mathrm{pH}$ and adult counts (Skei et al., 2006; Gustafson et al., 2009). Echoing Paterson (2018), we also found great crested newts were active at lower air temperatures than expected by current guidelines (English Nature, 2001; Langton et al., 2001). Furthermore, we uncovered a positive influence of moon visibility in combination with air temperature and moon phase on adult counts. However, further study of lunar periodicity in great crested newts in relation to breeding activity and reproduction is needed to understand this effect (Grant et al., 2012). 


\section{CONCLUSIONS}

Our study provides evidence for conservation management of great crested newt populations according to geographic location. Blanket monitoring guidelines may not be applicable to all populations and produce misleading data on temporal trends. We advocate fresh consideration of survey and pond suitability criteria for great crested newts in Scotland. Specifically, air temperature at which surveys can be performed (currently $5^{\circ} \mathrm{C}$ ) should be lowered to $3-4^{\circ} \mathrm{C}$ (Paterson, 2018; Harper et al., 2018), and moon visibility and phase during survey recorded. Ultimately, the most appropriate temperature for survey must be determined by modelling of detection probability using data generated by multi-method surveys over several consecutive weeks in the breeding season. Further pond creation and management is required to improve habitat suitability for the great crested newts at Gartcosh. Continued monitoring of this population is also necessary to confirm the nature of the effects reported here, and post-translocation status.

\section{ACKNOWLEDGEMENTS}

We thank all who assisted with the research summarised here. Scottish Natural Heritage, Glasgow Natural History Society, and the University of Glasgow provided financial support. Heritage Environmental Ltd., URS Corporation Ltd. and Acorna Associates Ltd. contributed survey data. Erik Paterson and Pete Minting provided training for great crested newt survey licence, and Froglife supplied torches for torchlight survey. Pardeep Chand, Ben Ross, and Barbara Mable offered their guidance and support to this research. Dan Haydon and Robert Paton troubleshot $\mathrm{R}$ code and statistical analysis. Finally, this research would not be possible without the dedicated volunteers who helped Deborah and Lynsey to conduct their surveys.

\section{REFERENCES}

English Nature (2001). Great Crested Newt Mitigation Guidelines. Peterborough, English Nature.

Grant, R., Halliday, T. \& Chadwick, E. (2012). Amphibians' response to the lunar synodic cyclea review of current knowledge, recommendations, and implications for conservation. Behavioural Ecology 24, 53-62.

Gustafson, D.H., Andersen, A.S.L., Mikusińsk, G. \& Malmgren, J.C. (2009). Pond quality determinants of occurrence patterns of great crested newts (Triturus cristatus). Journal of Herpetology 43, 300-310.

Harper, L.R., McNeill, D.C. \& Downie, J.R. (2017). The latest chapter in a conservation story: completing 10 years of post-translocation monitoring for a population of great crested newt (Triturus cristatus) in Scotland. The Glasgow Naturalist 26(4), 29-44.

Harper, L.R., Downie, J.R. \& McNeill, D.C. (2018). Assessment of habitat and survey criteria for great crested newts (Triturus cristatus) in Scotland: a case study on a translocated population. Hydrobiologia In Press.

Langton, T., Beckett, C. \& Foster, J. (2001). Great Crested Newt Conservation Handbook. Froglife, Halesworth.

McInerny, C.J. \& Minting, P.J. (2016). The Amphibians and Reptiles of Scotland. Glasgow Natural History Society, Glasgow.

McNeill, D.C., Downie, J.R. \& Ross, B. (2012). Gartcosh great crested newts: the story so far. The Glasgow Naturalist 25(4), 87-91.

Minting, P.J. (2018). Great Crested Newt Detectives: citizen science, education and DNA technology. ARC-UK, Bournemouth. www.arc-trust.org/News/aabs-book-launch

O’Brien, D., Hall, J., Miró, A. \& Wilkinson, J. (2017). Testing the validity of a commonly-used habitat suitability index at the edge of a species' range: great crested newt Triturus cristatus in Scotland. Amphibia-Reptilia 38, 265-273.

Oldham, R.S., Keeble, J., Swan, M.J.S. \& Jeffcote, M. (2000). Evaluating the suitability of habitat for the great crested newt (Triturus cristatus). Herpetological Journal 10, 143-155.

Paterson, E. (2018). Changes in relative population size detection rates of great crested newts (Triturus cristatus) over time. Herpetological Bulletin 143, 12-17.

Skei, J.K., Dolmen, D., Rønning, L. \& Ringsby, T.H. (2006). Habitat use during the aquatic phase of the newts Triturus vulgaris (L.) and T. cristatus (Laurenti) in central Norway: proposition for a conservation and monitoring area. AmphibiaReptilia 27, 309-324.

Unglaub, B., Steinfartz, S., Drechsler, A. \& Schmidt, B.R. (2015). Linking habitat suitability to demography in a pond-breeding amphibian. Frontiers in Zoology 12, 9. 